\title{
Biofield Energy Treatment Based Test Formulation as a Novel and Efficient Approach on Various Biomarkers in human Bones, Heart, Liver, Lungs, and Brain Cells
}

\author{
Streicher LN1 ${ }^{1}$, Trivedi MK$^{1}$, Branton $A^{1}$, Trivedi $D^{1}$, Nayak G $^{1}$, \\ Gangwar $\mathbf{M}^{2}$ and Jana $\mathrm{S}^{2 *}$ \\ ${ }^{1}$ Trivedi Global, Inc., Henderson, USA \\ ${ }^{2}$ Trivedi Science Research Laboratory Pvt. Ltd., India

\section{Research Article} \\ Volume 3 Issue 3 \\ Received Date: June 14, 2019 \\ Published Date: July 05, 2019 \\ DOI: $10.23880 /$ oajpr-16000180
}

*Corresponding author: Snehasis Jana, Trivedi Science Research Laboratory Pvt. Ltd., Thane-West, Maharashtra, India, Email: publication@trivedieffect.com

\section{Abstract}

Multiple organ dysfunction syndromes (MODS) are one of the common reasons for increased mortality rate against healthcare services. The present experiment aimed to determine the impact of the Biofield Energy Treated test formulation on the function of vital organs such as bones, heart, liver, lungs, and brain using standard activity parameters in specific cell-based assays. The test formulation and cells medium was divided into two parts; one untreated (UT) and other part received the Biofield Energy Treatment remotely by a renowned Biofield Energy Healer, Laura Nelson Streicher, and USA and were labeled as the Biofield Energy Treated (BT) test formulation/media. The test formulation was tested against various activities using cell line assay. The test formulation was tested for cell viability, and the results showed that the test formulation was found non-toxic against all the cell lines at the tested concentrations. Cytoprotective activity among the experimental groups showed a significant improved activity by $156.9 \%$ at $1 \mu \mathrm{g} / \mathrm{mL}$ in UT- medium (Med) + BT - test item/formulation (TI) group in human cardiac fibroblasts cells (HCF) cells, while $94.5 \%$ at $25.5 \mu \mathrm{g} / \mathrm{mL}$ in the UT-Med + BT-TI group in human hepatoma cells (HepG2), and $92.4 \%$ at $63.75 \mu \mathrm{g} / \mathrm{mL}$ in the BT-Med + BT-TI group as compared with the untreated test group in adenocarcinomic human alveolar basal epithelial cells (A549) cells as compared with the untreated test group. Alkaline phosphatase (ALP) activity in MG-63 cells was significantly increased by $80.2 \%$ and $93.5 \%$ at 10 and $50 \mu \mathrm{g} / \mathrm{mL}$ respectively in the UT-Med + BT-TI group, while in Ishikawa cells showed maximum increased ALP activity by $51.5 \%$ at $1 \mu \mathrm{g} / \mathrm{mL}$ in UT-Med + BT-TI group as compared to the untreated group. The percent protection of HCF (heart) cells (decreased of lactate dehydrogenase-LDH activity) was significantly increased by $156.9 \%$ and $18.3 \%$ at 1 and $10 \mu \mathrm{g} / \mathrm{mL}$ concentrations respectively, in UT-Med + BT-TI group, while BT-Med + UT-TI group showed increased protection by $24.5 \%$ and $17.7 \%$ at10 and $25.5 \mu \mathrm{g} / \mathrm{mL}$ respectively, and $67.1 \%, 32.2 \%, 47.7 \%$, 


\section{Open Access Journal of Pharmaceutical Research}

and 73.1\% improved cellular protection 1, 10, 25.5, and $63.75 \mu \mathrm{g} / \mathrm{mL}$ respectively, in BT-Med + BT-TI group as compared to the untreated test group. Alanine amino transferase (ALT) in terms of percent protection of HepG2 (liver) cells (decreased of ALT activity) was reported by $93.1 \%$ and $64.1 \%$ at $1 \mu \mathrm{g} / \mathrm{mL}$ in the UT-Med + BT-TI and BT-Med + UT-TI groups, respectively as compared to the untreated group. Cellular protection of A549 (lungs) cells (increased of superoxide dismutase-SOD activity) in terms of percentage was increased by $20.6 \%$ (at $0.1 \mu \mathrm{g} / \mathrm{mL}$ ) and $6.9 \%$ (at 10 $\mu \mathrm{g} / \mathrm{mL}$ ) in the UT-Med + BT-TI and BT-Med + BT-TI groups, respectively as compared to untreated group. Serotonin level was significantly increased by 59.3\% (at $10 \mu \mathrm{g} / \mathrm{mL}$ ), 55.6\% (at $1 \mu \mathrm{g} / \mathrm{mL}$ ), and $100.1 \%$ (at $0.1 \mu \mathrm{g} / \mathrm{mL}$ ) in the UT-Med + BTTI, BT-Med + UT-TI, and BT-Med + BT-TI groups, respectively compared to untreated in human neuroblastoma cells (SHSY5Y). However, the relative quantification (RQ) of vitamin D receptor (VDR) was significantly increased by $150.6 \%$ (at $50 \mu \mathrm{g} / \mathrm{mL}$ ), 380.1\% (at $10 \mu \mathrm{g} / \mathrm{mL}$ ), and 148.1\% (at $50 \mu \mathrm{g} / \mathrm{mL}$ ) in the UT-Med + BT-TI, BT-Med + UT-TI, and BT-Med + BTTI groups, respectively as compared to the untreated in MG-63 cells. In conclusion, test formulation would be significantly useful for multiple organ health and improve overall health of bones, heart, liver, lungs, and brain after treatment with the Biofield Energy treated test formulation (The Trivedi Effect ${ }^{\circledR}$ ). As a complementary and alternative therapy, Biofield Energy approach can be used against coronary artery disease, arrhythmias, congenital heart disease, cardiomyopathy, cirrhosis, liver cancer, hemochromatosis, asthma, chronic bronchitis, cystic fibrosis, osteoporosis, etc.

Keywords: The Trivedi Effect ${ }^{\circledR}$; Biofield energy treatment; Cardiac health; Liver health; Lungs health; VDR receptors; Brain health; Bone health

Abbreviations: HCF: Human Cardiac Fibroblasts Cells; $t$-BHP: tert-Butyl Hydroperoxide; ALP: Alkaline Phosphatase; LDH: Lactate Dehydrogenase; ROS: Reactive Oxygen Species; qPCR: Quantitative-Polymerase Chain Reaction; WHO: World Health Organization; VDR: Vitamin D Receptor; AD: Alzheimer's Disease; UC: Ulcerative Colitis; IBS: Irritable Bowel Syndrome; RQ: Relative Quantification; SOD: Superoxide Dismutase; TMZ: Trimetazidine; HK: House-Keeping.

\section{Introduction}

Over the past several years, development of herbal based novel drugs has been developed against wide range of pathological diseases. However, due to continuing acceptance of alternative drugs as one of the major step towards treatment approach, a novel test formulation was designed to test wide range of activities on various biomarkers in human bones, heart, liver, lungs, and brain cells. The test formulation is the combination of 11 ingredients, calcium chloride, panax ginseng extract, vitamin $B_{12}$, beta carotene, vitamin $D_{3}$, zinc chloride, magnesium gluconate, sodium selenate, ferrous sulfate, ascorbic acid and vitamin $\mathrm{B}_{6}$. Panax ginseng is available in various forms in the market as the only product that maintain the natural energy, improved mental and physical abilities, moods and enhance the general health and well-being [1]. Overall, Panax ginseng is one of the best immunomodulator, enhances the cognitive function, improve heart action, and also reported to be useful in many health illness and infections. Besides, this was reported to be effective against lung disorder, liver disorder, breast cancer, liver cancer, aging, muscle damage, and overall health [2]. In addition, the novel test formulation contain vital minerals and vitamins, these are the diverse group of substances, which are important in numerous biological processes. In comparison to the vital body nutrients, such as carbohydrates, fats, and protein body required very small amounts of vitamins and minerals for overall growth of the body to fight against wide variety of acute and chronic diseases [3]. Selenium, calcium, zinc, iron, etc are the crucial minerals that play major role in immunomodulation, neuronal balance and many more $[4,5]$. Thus, this novel formulation is supposed to be effective against wide range of pathological conditions with respect to health of major vital organs such as bones, heart, liver, lungs, and, brain, as 


\section{Open Access Journal of Pharmaceutical Research}

nutraceutical formulations have high acceptance rate among the healthcare populations [6]. Besides, more than $80 \%$ world population relies on herbal based complementary drugs $[7,8]$. The present study was designed to evaluate the effect of novel test formulation after treatment with the Biofield Energy Healing Treatment against various cell lines for bone health (MG63 cells, Human Osteoblasts like Cells), liver health (ALT estimation using HepG2, Human liver cell line), lung health (SOD activity in A549, Human lung adenocarcinoma cell line), heart health (LDH activity in Human Cardiac fibroblasts cells), female reproductive functions (using Ishikawa cells, Human Endometrial cancer cell line), memory and cognitive health (using estimation of serotonin release using SH-SY5Y, Human Neuroblastoma Cells) [9-18]. Overall, studies suggested that high mortality rate worldwide was due to cardiovascular disorders, multiple organ failure, and all are somehow related with the generation of free radicals, which are responsible for the onset of these health issues $[19,20]$.

Thus, the present study was aimed to detect the overall health status using novel test formulation. Biofield Energy Healing Treatment as a complementary approach was used to alter the overall action of test formulation. However, Complementary and Alternative Medicine (CAM) concept and its associated therapies have been reported with significant clinical and non-clinical benefits $[21,22]$. Biofield Energy Healing Therapies have been practiced and accepted by the U.S. population and is concluded by National Center for Complementary and Alternative Medicine (NCCAM) [23,24]. CAM therapies such as external qigong, Johrei, Reiki, therapeutic touch, yoga, Qi Gong, polarity therapy, Tai Chi, pranic healing, deep breathing, chiropractic/osteopathic manipulation, guided imagery, meditation, massage, homeopathy, hypnotherapy, progressive relaxation, acupressure, acupuncture, special diets, relaxation techniques, Rolfing structural integration, healing touch, movement therapy, pilates, mindfulness, Ayurvedic medicine, traditional Chinese herbs and medicines in biological systems. The Trivedi Effect ${ }^{\circledR}$-Consciousness Energy Healing therapies have been widely accepted worldwide in nonliving materials and living organisms. Consciousness Energy Healing Treatment found to be significant to improve the metal physicochemical properties $[25,26]$, improved crop yield in agriculture science [27], microbiology [28,29], biotechnology [30,31], improved bioavailability of many compounds [32,33], improved skin health [34,35], improved properties of nutraceuticals [36], cancer science research [37], improved overall bone health [38-
40], human health and wellness. Due to the continued outcomes and wide applications of Biofield Energy Healing Treatments, the test formulation was studied for impact of the Biofield Energy Healing Treated test formulation on the function of vital organs such as bones, heart, liver, lungs, and brain specific biomarkers in different cell-lines.

\section{Materials and Methods}

\section{Chemicals and Reagents}

The constituents used in the experiment such as ferrous sulfate, vitamin $B_{6}$, vitamin $D_{3}$, vitamin $B_{12}$, calcium chloride, naringenin, trimetazidine (TMZ), 3-(4,5Dimethylthiazol-2-yl)-2,5-Diphenyltetrazolium Bromide (MTT), and ethylenediaminetetraacetic acid (EDTA) were collected from Sigma Chemical Co. (St. Louis, MO). In addition, zinc chloride, magnesium gluconate, $\beta$-carotene, and calcitriol were procured from TCI chemicals, Japan. Panax ginseng extract obtained from panacea Phytoextracts, India. Sodium selenate and ascorbic acid were obtained from Alfa Aesar, India. Silymarin and curcumin were obtained from Sanat Chemicals, India and quercetin was purchased from Clearsynth, India. Reverse Transcription Kit, RNeasy Mini Kit, and Syber Green PCR kits were procured from Qiagen, India. All the other chemicals used in this experiment were analytical grade procured from India.

\section{Biofield Energy Healing Treatment}

Biofield Energy Healing was done on the test formulation, which was the combination of eleven ingredients viz. calcium chloride, panax ginseng extract, vitamin $B_{12}, \beta$-carotene, vitamin $D_{3}$, zinc chloride, magnesium gluconate, sodium selenate, ferrous sulfate, ascorbic acid, and vitamin $\mathrm{B}_{6}$. The test formulation was divided into two parts, one portion was considered as the untreated group, where no Biofield Energy Treatment was provided. Further, the untreated group was treated with a "sham" healer for comparison purposes with other experimental groups. The "sham" healer did not have any knowledge about the Biofield Energy Healing Treatment. The other portion of the formulation received the Biofield Energy Treatment (The Trivedi Effect ${ }^{\circledR}$ ) remotely by Laura Nelson Streicher, under standard laboratory conditions for $\sim 3$ minutes through healer's unique Biofield Energy Transmission process and was referred as the Biofield Energy Treated formulation. The Biofield Energy Healer was located in the USA, however the test formulation constituents were located in the research laboratory of Dabur Research Foundation, New Delhi, 
India. Biofield Energy Healer in this experiment did not visit the laboratory, nor had any contact with the test samples. After that, the Biofield Energy Treated and untreated test items were kept in similar sealed conditions and used for the study as per the study plan.

\section{Assessment of Cell Viability Using MTT Assay}

All the cells were counted for cell viability using hemocytometer in 96-well plates at the specific density as mentioned in the Table 1 . The cells were then incubated overnight under standard growth conditions to allow cell recovery and exponential growth. Following overnight incubation, cells were treated with different concentrations of test formulations (BT/UT). After respective treatments, the cells were incubated in a $\mathrm{CO}_{2}$ incubator at $37^{\circ} \mathrm{C}, 5 \% \mathrm{CO}_{2}$, and $95 \%$ humidity. After incubation, the plates were taken out and $20 \mu \mathrm{L}$ of 5 $\mathrm{mg} / \mathrm{mL}$ of MTT 3-(4,5-dimethythiazol-2-yl)-2,5-diphenyl tetrazolium bromide solution was added to all the wells followed by additional incubation for 3 hours at $37^{\circ} \mathrm{C}$. The supernatant was aspirated and $150 \mu \mathrm{L}$ of DMSO was added to each well to dissolve formazan crystals. The absorbance of each well was read at $540 \mathrm{~nm}$ using Synergy HT microplate reader. The percentage cytotoxicity at each tested concentration was calculated using Equation 1:

$\%$ Cytotoxicity $=[(\mathrm{R}-\mathrm{X}) / \mathrm{R}] * 100$.

Where, $\mathrm{X}=$ Absorbance of treated cells; $\mathrm{R}=$ Absorbance of untreated cells

The concentrations exhibiting percentage cytotoxicity $<30 \%$ was considered as non-cytotoxic [41].

\begin{tabular}{|c|c|c|c|}
\hline S. No. & Cell Line & Plating & Time Point \\
\hline 1 & MG-63 (Bone) & $3 \times 10^{4}$ cells/ well, 96-well plate & 5 days \\
\hline 2 & Ishikawa (Uterus) & $3 \times 10^{4}$ cells/ well, 96-well plate & 5 days \\
\hline 3 & A549 (Lung) & $10 \times 10^{4}$ cells/ well, 96-well plate & 24 hours \\
\hline 4 & HepG2 (Liver) & $1 \times 10^{4}$ cells/ well, 96-well plate & 24 hours \\
\hline 5 & Human Cardiac fibroblasts (Heart) & $1 \times 10^{4}$ cells/ well, 96-well plate & 24 hours \\
\hline 6 & SH-SY5Y (Neuronal cell) & $10 \times 10^{4}$ cells/ well, 96-well plate & 24 hours \\
\hline
\end{tabular}

Table 1: Information related to six cell lines with their plating density and time-point.

\section{Evaluation of the Cytoprotective Effect of the Formulation}

Cytoprotective effect of the test formulation in various cells such as human cardiac fibroblasts-HCF; human hepatoma cells-HepG2; and adenocarcinomic human alveolar basal epithelial cells-A549 were counted and plated in suitable medium followed by overnight incubation. Further, the cells were then treated with the test items/positive control at the non-cytotoxic concentrations for 24 hours. After 24 hours, the oxidative stress using $10 \mathrm{mM} t$-BHP for 3.5 hours was given to the cells. The cells treated with $10 \mathrm{mM}$ of $t$-BHP alone served as negative control. After 3.5 hours of incubation with $t$ BHP the above plates were taken out and cell viability was determined by MTT assay. The percentage protection corresponding to each treatment was calculated using equation 2:

$\%$ Protection $=\left[\left(\text { Absorbance }_{\text {sample }}-\text { Absorbance }_{\mathrm{t}-\mathrm{BHP}}\right)\right]^{*} 100 /$

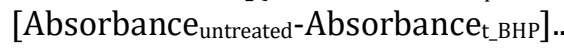

\section{Estimation of Alkaline Phosphatase (ALP) Activity}

For the estimation of ALP, the cells (human bone osteosarcoma cells-MG-63 and human endometrial adenocarcinoma cells-Ishikawa) were counted using a hemocytometer and plated in 24-well plates at the density corresponding to $1 \times 10^{4}$ cells/well in phenol-free DMEM supplemented with $10 \%$ CD-FBS. Following the respective treatments, the cells in the above plate were incubated for 48 hours in $\mathrm{CO}_{2}$ incubator at $37^{\circ} \mathrm{C}, 5 \% \mathrm{CO}_{2}$, and $95 \%$ humidity. After 48 hours of incubation, the plates were taken out and processed for the measurement of ALP enzyme activity. The cells were washed with $1 \mathrm{X}$ PBS and lysed by freeze-thaw method i.e., incubation at $80^{\circ} \mathrm{C}$ for 20 minutes followed by incubation at $37^{\circ} \mathrm{C}$ for 10 minutes. To the lysed cells, $50 \mu \mathrm{L}$ of substrate solution i.e. $5 \mathrm{mM}$ of $p$-nitrophenyl phosphate $(p N P P)$ in $1 \mathrm{M}$ diethanolamine and $0.24 \mathrm{mM}$ magnesium chloride $\left(\mathrm{MgCl}_{2}\right)$ solution ( $\left.\mathrm{pH} 10.4\right)$ was added to all the wells followed by incubation for 1 hour at $37^{\circ} \mathrm{C}$. The absorbance of the above solution was read at $405 \mathrm{~nm}$ using Synergy HT microplate reader (Biotek, USA). The absorbance 


\section{Open Access Journal of Pharmaceutical Research}

values obtained were normalized with substrate blank ( $p$ NPP solution alone) absorbance values. The percentage increase in ALP enzyme activity with respect to the untreated cells (baseline group) was calculated using Equation 3:

$\%$ Increase in ALP $=\{(X-R) / R\}^{*} 100$

Where, $\quad X=$ Absorbance of cells corresponding to positive control and test groups

$\mathrm{R}=$ Absorbance of cells corresponding to baseline group (untreated cells)

\section{Estimation of Lactate Dehydrogenase (LDH) In Human Cardiac Fibroblasts (HCF) Cells}

HCF cells were counted and plated at the density of $0.25 \times 10^{6}$ cells/ well in 24-well plates in cardiac fibroblast specific mediumfollowed by overnight incubation. The cells were then treated with the test formulation combinations/positive control at the noncytotoxic concentrations for 24 hours. After 24 hours, oxidative stress was given to the cells using $10 \mathrm{mM} t$-BHP for 3.5 hours. The untreated cells were served as control group, which did not receive any treatment and were maintained in cell growth medium only. Cells treated with $10 \mathrm{mM}$ of $t$-BHP alone served as the negative control. After 3.5 hours of incubation with $t$-BHP, the above plates were taken out and LDH activity was determined using LDH activity kit as per manufacturer's instructions. The percent increase in LDH activity was calculated using Equation 4.

$\%$ Increase $=\left[\left(\mathrm{LDH}\right.\right.$ activity sample $^{-\mathrm{LDH}}$ activityt-BHP $\left.)\right] * 100 /$

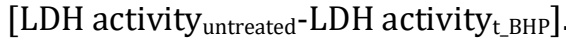

\section{Estimation of ALT in Liver Cells (HepG2)}

The human hepatoma cells (HepG2) were counted and plated at the density of $5 \times 10^{4}$ cells/well in 48-well plates in DMEM media followed by overnight incubation. The cells were then treated with the test formulation/positive control at the non-cytotoxic concentrations for 24 hours. After 24 hours, oxidative stress was given to the cells using $400 \mu \mathrm{M} t$-BHP for 3.5 hours. The untreated cells served as control that did not receive any treatment and were maintained in cell growth medium only. Cells treated with $400 \mu \mathrm{M}$ of $t$-BHP alone served as negative control. After 3.5 hours of incubation with $t$-BHP, the above plates were taken out and ALT activity was determined using ALT activity kit as per manufacturer's instructions. The percent increase in ALT activity was calculated using Equation 5.
$\%$ Increase $=[(\text { ALT activity } \text { sample }-\mathrm{ALT} \text { activityt-BHP })]^{* 100 /}$

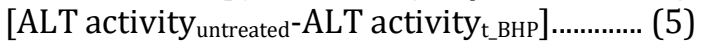

\section{Estimation of Superoxide Dismutase (SOD) in Lung (A549) Cells}

The adenocarcinomic human alveolar basal epithelial cells (A549) were counted and plated at the density of $1 \mathrm{X}$ $10^{4}$ cells/well in 24-well plates in DMEM followed by overnight incubation. The cells were then treated with the test formulation/positive control at the non-cytotoxic concentrations along with $100 \mu \mathrm{M} t$-BHP to induce oxidative stress. The untreated cells served as control that did not receive any treatment and were maintained in cell growth medium only. Cells treated with $100 \mu \mathrm{M}$ of $t$-BHP alone served as negative control. After 24 hours of incubation with $t$-BHP the above plates were taken out and SOD activity was determined using SOD activity kit as per manufacturer's instructions. The percent increase in SOD activity was calculated using equation 6 :

$\%$ Increase in SOD activity $=((\mathrm{X}-\mathrm{R}) / \mathrm{R}) * 100$.

Where, $\mathrm{X}=$ SOD activity corresponding to test item or positive control

$\mathrm{R}=\mathrm{SOD}$ activity corresponding to Control group.

\section{Estimation of Serotonin in Neuronal Cells (SH- SY5Y)}

The human neuroblastoma (SH-SY5Y) cells were counted and plated at the density of $10 \times 10^{4}$ cells/well in 96-well plates followed by overnight incubation. The cells were then treated with the test formulation/positive control at the non-cytotoxic concentrations. The untreated cells served as control that did not receive any treatment and were maintained in cell growth medium only. The treated cells were incubated for 24 hours. Serotonin release was determined by ELISA as per manufacturer's protocol. The percent increase in serotonin levels was calculated using equation 7-

$$
[(\mathrm{X}-\mathrm{R}) / \mathrm{R}] * 100 \text {. }
$$

Where, $X=$ Serotonin levels corresponding to test item or positive control,

$\mathrm{R}=$ Serotonin levels corresponding to control group.

\section{Effect of Test Formulation on Vitamin D Receptor (VDR) in Bone (MG-63) Cells}

The effect of test formulation on vitamin $\mathrm{D}$ receptor (VDR) activity in bone (MG-63) cells were counted using the hemocytometer at density $2 \times 10^{5}$ cells/well in 6-well plates followed by overnight incubation. The cells were then sera starved for 24 hours and treated with the test 


\section{Open Access Journal of Pharmaceutical Research}

formulation/positive control at the non-cytotoxic concentrations, while control group did not receive any treatment, which were maintained in cell growth medium only. The treated cells were incubated for 24 hours and VDR expression was determined by qPCR using VDR specific primers. Cells were harvested by scrapping and washed with PBS. Cell pellets obtained were analyzed for VDR gene expression using human VDR specific primers: Forward: 5'-GCTGACCTGGTCAGTTACAGCA-3', Reverse: 5'-CACGTCACTGACGCGGTACTT-3'. VDR gene expression was normalized using House-keeping (HK) reference. Relative quantification (RQ) of VDR gene in Biofield Energy Treated cells was calculated with respect to the untreated cells using equation 8 :

$$
\mathrm{RQ}=2-\mathrm{N}
$$

Where, $\mathrm{N}$ is the relative Threshold Cycle $\left(\mathrm{C}_{\mathrm{T}}\right)$ value of treated sample with respect to the untreated sample.

\section{Statistical Analysis}

All the values were represented as mean \pm SD (standard deviation) of three independent experiments. The statistical analysis was performed using SigmaPlot statistical software (v11.0). For two group comparison, student's $t$-test was used. For multiple group comparison, one-way analysis of variance (ANOVA) was used followed by post-hoc analysis by Dunnett's test. Statistically significant values were set at the level of $p \leq 0.05$.

\section{Results and Discussion}

\section{Cell Viability Using MTT Assay}

MTT assay data in each cell line showed various percentage of cell viability. The criteria for non-cytotoxic test formulation concentration and the positive controls by MTT cell viability assay was resulted in less than $30 \%$ cytotoxicity or greater than $70 \%$ cell viability were considered as non-cytotoxic concentrations. Overall, the experimental data suggested more than $70 \%$ cell viability in different cell-lines viz. MG-63, Ishikawa, A549, HepG2, HCF, and SH-SY5Y. Based on the percent cell viability data, it was observed that the test formulation and positive controls were found safe and non-toxic at the tested concentrations and were selected for other parameters.

\section{Evaluation of Cytoprotective Effect of the Test Formulation}

The cytoprotective activity in terms of percentage cell protection was identified against $t$-BHP induced cell damage and the results are presented in the Figure 1. Trimetazidine (TMZ), positive control group in human cardiac fibroblasts cells (HCF) showed significant restoration of cell viability by $34 \%, 60 \%$, and $98.3 \%$ at 5 , 10 and $25 \mu \mathrm{g} / \mathrm{mL}$, respectively as compared to the $t$-BHP induced group. Besides, the maximum restoration of cell viability among the tested groups by the test formulation was reported as $156.9 \%$ (at $1 \mu \mathrm{g} / \mathrm{mL}$ ), $24.5 \%$ (at 10 $\mu \mathrm{g} / \mathrm{mL}$ ), and $67.1 \%$ (at $1 \mu \mathrm{g} / \mathrm{mL}$ ) in the UT-Med + BT-TI, BT-Med + UT-TI, BT-Med + BT-TI groups respectively, as compared to the untreated test group (UT-Med + UT-TI group). Similarly, silymarin was used as positive control in HepG2 cells, which resulted in significant cellular restoration by $40 \%, 65.9 \%$, and $86.6 \%$ at 5,10 and 25 $\mu \mathrm{g} / \mathrm{mL}$ respectively, as compared to the $t$-BHP induced group. Besides, the test formulation showed maximum restoration of cell viability by $83.5 \%, 7.5 \%, 94.5 \%$, and $57.1 \%$ at $1,10,25.5$, and $63.75 \mu \mathrm{g} / \mathrm{mL}$ respectively, in the UT-Med + BT-TI group. Similarly, 46.8\%, 31.3\%, and $48.6 \%$ improved cellular restoration was reported at 1 , 10 , and $25.5 \mu \mathrm{g} / \mathrm{mL}$ respectively, at BT-Med + BT-TI groups as compared to the UT-Med + UT-TI group. In addition, quercetin was used as positive control in adenocarcinomic human alveolar basal epithelial cells (A549) resulted, restoration of cell viability by $56.8 \%$ and $66.4 \%$ at 10 and $25 \mu \mathrm{g} / \mathrm{mL}$, respectively compared to the $t$-BHP induced group. Besides, the test formulation showed maximum restoration of cell viability at 63.75 $\mu \mathrm{g} / \mathrm{mL}$ by $49.8 \%, 61.7 \%$, and $92.4 \%$ in the UT-Med + BTTI, BT-Med + UT-TI, BT-Med + BT-TI groups, respectively as compared to the UT-Med + UT-TI group. Oxidative damage in all the three cells were initiated followed by identification of percentage cytoprotective activity that showed the cellular protection of vital organs and their functioning viz. heart, liver, and lungs. The activity of the test formulation was examined in the in vitro cell-based assays under the stimulation of oxidative stress in different cell-lines using tert-butyl hydroperoxide ( $t$-BHP) $[41,42]$. Cellular damage has been reported because of high incidence of oxidative stress, which is the initiating factor for many pathological diseases [41,43]. Besides, cellular damage due to oxidative stress results in many age-related disorders such as diabetes, cardiovascular, autoimmune diseases, and cancer [44-46]. The experimental data revealed that Biofield Energy Healing Treatment significantly protects the $t$-BHP induced oxidative stress in all the three cell lines with respect to cardiotoxicity, hepatotoxicity, and lung cell toxicity. However, it was assumed that this significant activity could be due to The Trivedi Effect ${ }^{\circledR}$. Therefore, the Biofield Energy Healing Treatment could be successfully used for the management of various pathological etiologies against cardiovascular, liver, and various lung diseases. 


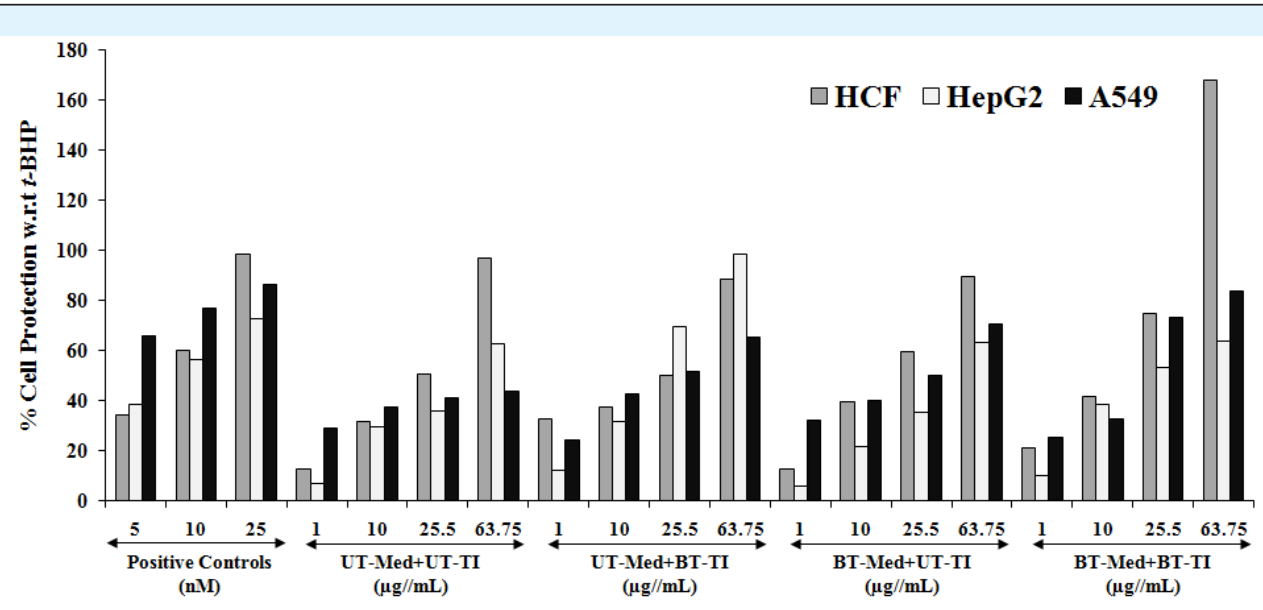

Figure 1: Assessment of cytoprotective effect of the test formulation in human cardiac fibroblasts cells (HCF), human hepatoma cells (HepG2), and adenocarcinomic human alveolar basal epithelial cells (A549) against tert-butyl hydroperoxide $(t$-BHP) induced damage. Trimetazidine $(\mu \mathrm{M})$, silymarin $(\mu \mathrm{g} / \mathrm{mL})$, and quercetin $(\mu \mathrm{M})$ were used as positive control in HCF, HepG2, and A549 cells, respectively. UT: Untreated; Med: Medium; BT: Biofield Treated; TI: Test item.

\section{Assessment of Alkaline Phosphatase (ALP) Activity}

ALP activity was assessed for test formulation and positive controls were used specifically against two cell lines, MG-63 and Ishikawa cells. Calcitriol (nM) was used as positive control for MG-63 cells and the results suggested significant increased ALP level by $12 \%, 23 \%$, and $53.5 \%$ at $0.1,1$, and $10 \mathrm{nM}$ respectively as presented in Figure 2. However, the test groups showed maximum increased ALP activity by $80.2 \%$ and $93.5 \%$ at 10 and 50 $\mu \mathrm{g} / \mathrm{mL}$ respectively, in the UT-Med + BT-TI, while $78.3 \%$ and $85.1 \%$ at 10 and $50 \mu \mathrm{g} / \mathrm{mL}$ respectively, in the BTMed + UT-TI group, and 19.2\%, 76.3\%, and $84 \%$ improved cellular protection at 1,10 and $50 \mu \mathrm{g} / \mathrm{mL}$ respectively, in the BT-Med + BT-TI group, as compared to the UT-Med + UT-TI group in MG-63 cells. Similarly, naringenin was used as positive control for Ishikawa cells, and the data showed significant improved level of ALP by $35.8 \%, 69.5 \%$, and $109.4 \%$ at 1,5 , and $10 \mathrm{nM}$, respectively.

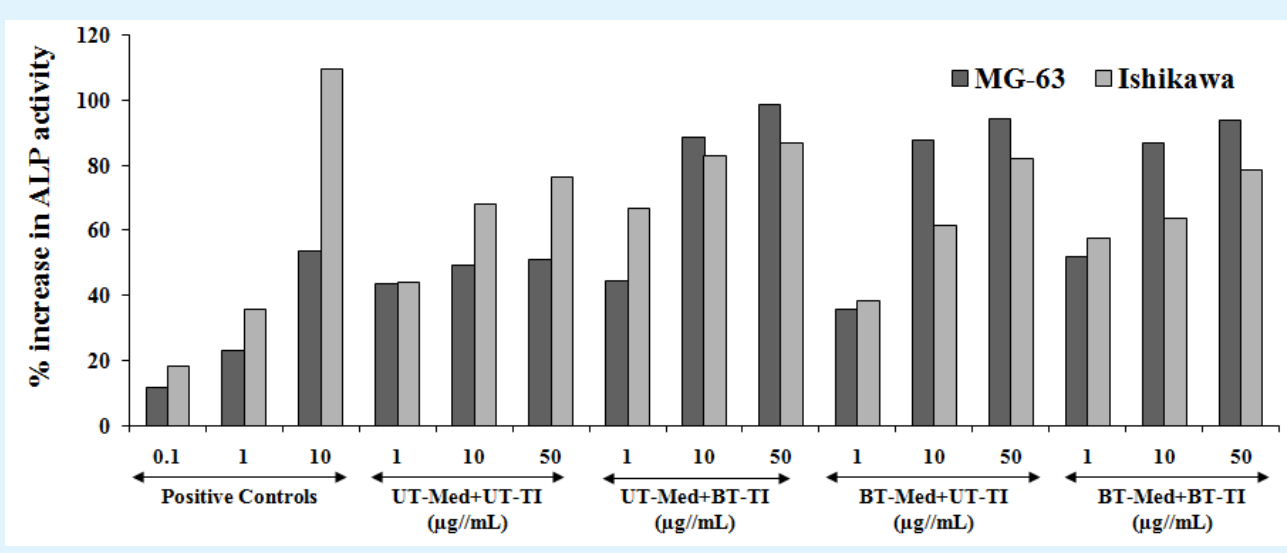

Figure 2: The effect of the test formulation on alkaline phosphatase (ALP) in human bone osteosarcoma cells (MG-63) and human endometrial adenocarcinoma cells (Ishikawa). Calcitriol and naringenin were used as positive control in MG-63 and Ishikawa cells, respectively. UT: Untreated; Med: Medium; BT: Biofield Treated; TI: Test item. 
In the experimental tested groups, the maximum ALP percent was significantly increased by $51.5 \%(1 \mu \mathrm{g} / \mathrm{mL})$, $7.6 \%(50 \mu \mathrm{g} / \mathrm{mL}$ ), and $30.1 \%$ (at $1 \mu \mathrm{g} / \mathrm{mL}$ ) in the UT-Med + BT-TI, BT-Med + UT-TI, BT-Med + BT-TI groups, respectively as compared to the UT-Med + UT-TI group. Estimation of ALP is considered as the major bone health biomarker, which signifies any initiation of degeneration of bone cells, which might results in bone disorders $[47,48]$. The present experimental data suggested that the Biofield Energy Healing Treated test formulation significantly increased the level of ALP expression that can be significantly recommended against any bonerelated disorders.

\section{Assessment of Lactate Dehydrogenase (LDH) Activity in Human Cardiac Fibroblasts (HCF)}

The lactate dehydrogenase (LDH) is mainly for anaerobic cellular respiration [49-51] and present in abundant in the heart and skeletal muscle, which are responsible for various conditions such as tissue injury, necrosis, hypoxia, hemolysis or malignancies. LDH activity of the test formulation was tested using HCF cells and the data was reported in terms of increased percentage protection, which suggested significant decreased LDH activity. The positive control, trimetazidine (TMZ) exhibited $34 \%, 60 \%$, and $98.3 \%$ cellular protection of $\mathrm{HCF}$ cells (decreased of LDH activity) at 5, 10, and $25 \mu \mathrm{M}$ concentration as compared to the $t$-BHP group. The effect of test formulation in different groups with respect to the percent protection of HCF cells in terms of decreased level of lactate dehydrogenase (LDH) activity is presented in Figure 3. Among the tested groups, the maximum percent protection of HCF cells (decreased of LDH activity) was significantly increased by $156.9 \%$ and $18.3 \%$ at 1 and 10 $\mu \mathrm{g} / \mathrm{mL}$ concentrations respectively, in the UT-Med + BTTI group, while $24.5 \%$ and $17.7 \%$ improved cellular protection (decreased of LDH activity) at10 and 25.5 $\mu \mathrm{g} / \mathrm{mL}$ respectively in the BT-Med + UT-TI group, and $67.1 \%, 32.2 \%, 47.7 \%$, and $73.1 \%$ improved cellular protection (decreased of LDH activity) at 1, 10, 25.5, and $63.75 \mu \mathrm{g} / \mathrm{mL}$ respectively, in BT-Med + BT-TI group as compared to the UT-Med + UT-TI group. The experimental data suggested that there was a significant reduction of LDH level after Biofield Energy Treatment and protect HCF cells, which might be helpful to resist against various pathological conditions. This Biofield Energy Treated test formulation would be one of the significant alternative treatment methods for improved cellular function of heart under any type of oxidative stressful situations.

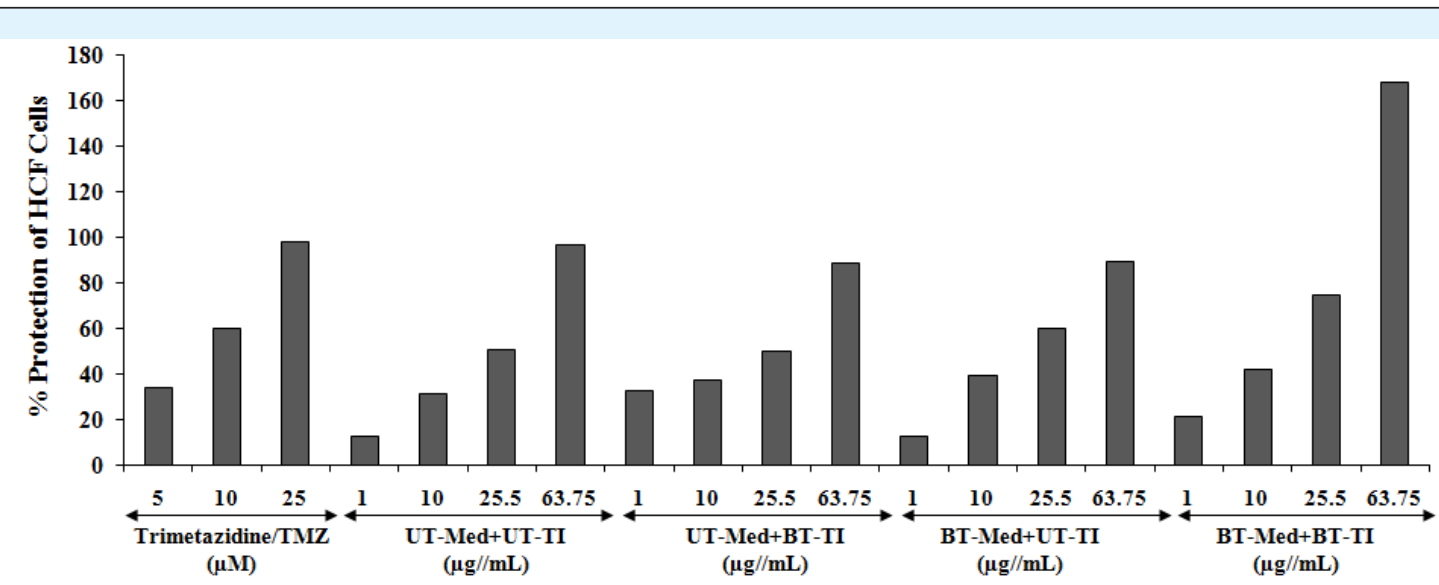

Figure 3: The effect of the test formulation on the percent protection of HCF cells in terms of decreased lactate dehydrogenase (LDH) activity against tert-butyl hydroperoxide ( $t$-BHP) induced damage. TMZ: Trimetazidine; UT: Untreated; Med: Medium; BT: Biofield Treated; TI: Test item.

\section{Estimation of Alanine Amino Transferase (ALT) Activity in HepG2 Cells}

Alanine amino transferase (ALT) is an enzyme, present in abundant mostly in the liver and kidney. However, liver and kidney are one of the largest internal organs of the human body that maintain overall health and quality of life. Thus, ALT alteration would directly reflect the hepatocellular injury and death [52]. Increased hepatoprotective effect was suggested by enhanced cellular viability against oxidative damage, while ALT increased level displays the chance of getting liver 
disorders [53]. ALT activity was evaluated using HepG2 cells protection and the results are presented in terms of decreased ALT activity (Figure 4). The positive control, silymarin was selected in ALT activity and the data suggested increased percentage cellular protection (decreased ALT activity) by $40.2 \%, 63.4 \%$, and $103.7 \%$ at 5,10 , and $25 \mu \mathrm{g} / \mathrm{mL}$ concentrations, respectively. Similarly, the test formulation groups showed improved cellular protection of HepG2 cells (decreased of ALT activity) by $93.1 \%, 20.3 \%$, and $10.8 \%$ at 1,10 , and 25.5 $\mu \mathrm{g} / \mathrm{mL}$ respectively, in the UT-Med + BT-TI group, while increased cellular protection of HepG2 cells (decreased of ALT activity) by $64.1 \%$ and $34.5 \%$ at 1 and $25.5 \mu \mathrm{g} / \mathrm{mL}$ respectively, in the BT-Med + UT-TI group, and increased cellular protection of HepG2 cells (decreased of ALT activity) by $9.1 \%, 11.5 \%$, and $33.4 \%$ at 1,10 , and 25.5 $\mu \mathrm{g} / \mathrm{mL}$ respectively, in the BT-Med + BT-TI group as compared to the UT-Med + UT-TI group (Figure 4). Therefore, the experimental data suggested Biofield Energy Treatment significantly protects the liver hepatocytes with reduced ALT enzyme as compared to the $t$-BHP inducing group.

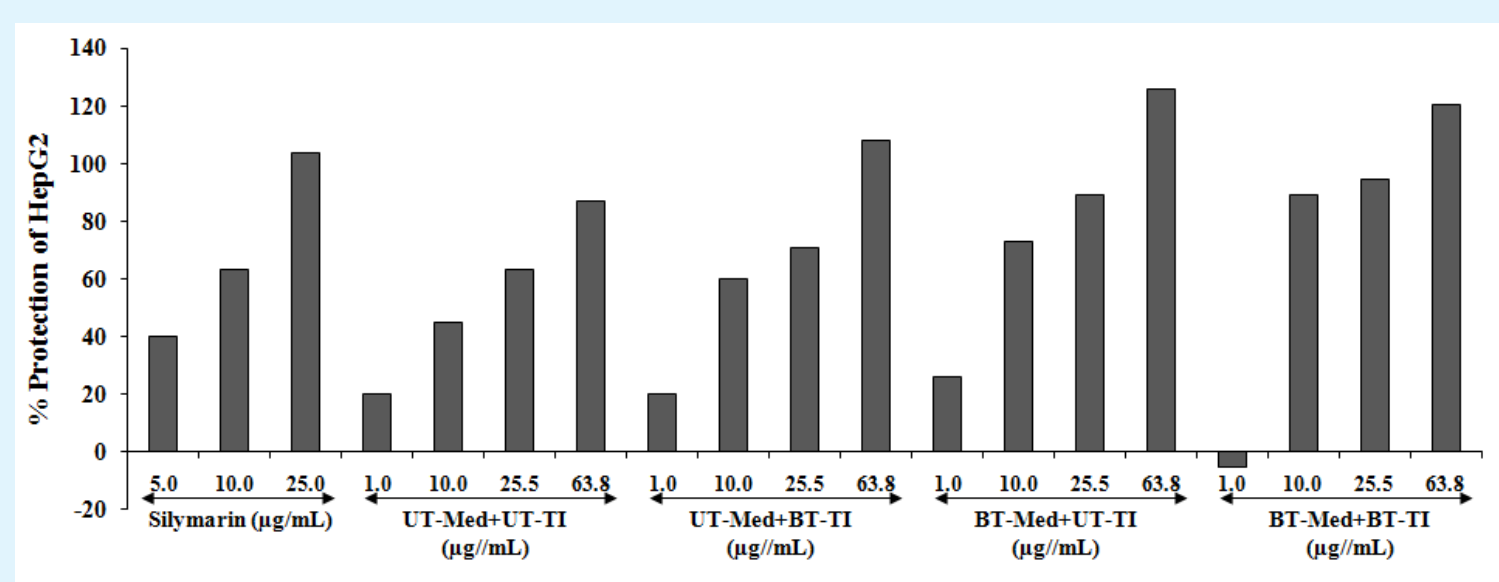

Figure 4: Effect of the test formulation on the percent protection of human liver cancer (HepG2) cells in terms of decreased alanine amino transaminase (ALT) activity under the stimulation of tert-butyl hydroperoxide ( $t$-BHP). UT: Untreated; Med: Medium; BT: Biofield Treated; TI: Test item.

\section{Estimation of Superoxide Dismutase (SOD) Activity in Adenocarcinomic Human Alveolar Basal Epithelial Cells (A549)}

Enzymes and free radicals are one of the important parts of our body, which is responsible for generation of oxidative stress. This occurred because of many factors and results in severe damage to most of the vital organs, which play a pivotal role towards increased ageing, various degenerative diseases, and cancer. However, it has been reported that various factors such as endogenously or exogenously like pollutants, cigarette smoke, etc. were exposed to the lungs causing respiratory illness and other inflammatory disorders. Besides, SOD is one of the important antioxidant defense mechanism of body. It has been reported that SOD enzyme based alternative treatment significantly reduced the ROS generation, oxidative stress along with inhibition of endothelial activation [54]. The present activity includes estimation of SOD enzyme in A549 cells and improved activity represents increased cellular protection and the data was presented in Figure 5. The positive control, quercetin showed improved percentage increase in the SOD activity with respect to the $t$-BHP by $68.4 \%, 83.9 \%$, and $104.2 \%$ at 10,25 , and $50 \mu \mathrm{g} / \mathrm{mL}$ concentration respectively. However, the percent protection of A549 (lungs) cells (increased of SOD activity) was significantly increased by $20.6 \%$ and $12.8 \%$ at 0.1 and $63.8 \mu \mathrm{g} / \mathrm{mL}$ respectively, in the UT-Med + BT-TI group, while increased SOD activity by $1.5 \%$ at $25.5 \mu \mathrm{g} / \mathrm{mL}$ in the BTMed + UT-TI group, and increased SOD activity by $6.9 \%$ at $10 \mu \mathrm{g} / \mathrm{mL}$ in the BT-Med + BT-TI group as compared to the UT-Med + UT-TI group (Figure 5). The experimental data showed that Biofield Energy Treatment has the significant capacity to improve the level of SOD enzyme that would be highly significant to resist against various respiratory diseases such as chronic obstructive pulmonary disease (COPD), pneumonia, asthma, pulmonary fibrosis, and lung cancer. 


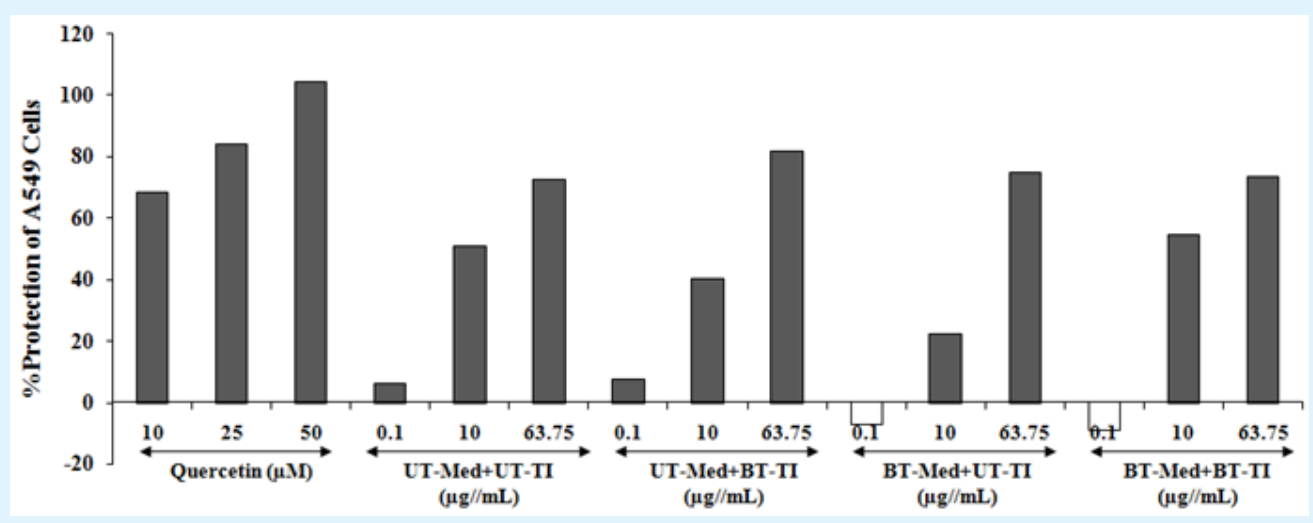

Figure 5: Effect of the test formulation on the percent protection of lungs cells (A549) in terms of increased SOD activity under the stimulation of tert-butyl hydroperoxide ( $t$-BHP). UT: Untreated; Med: Medium; BT: Biofield Treated; TI: Test item.

\section{Estimation of Serotonin Level in Human Neuroblastoma (SH-SY5Y) Cells}

Serotonin assay was performed using SH-SY5Y cells and the effect of test formulation was assessed after 24 hours of treatment using ELISA assay. 5-HT work as a transmit messages in nerve cells, while present in abundant in brain, bowels, and blood platelets. This supports active role in constricting the smooth muscle fibers. Besides, its role has been predefined in many neuronal functions such as sleep, feeding, pain, sexual behavior, cardiac regulation, and cognition. Serotonin imbalance results in many neuropsychiatric disorders such as depression, Alzheimer's disease, loss of ability of thinking, memory loss, cognitive health, etc. [55]. The present assay was performed to judge the effect of Biofield Energy Treated test formulation and the change in serotonin level are presented in Figure 6. The positive control, curcumin showed $66.3 \%, 115.1 \%$, and $143.4 \%$ increase the level of serotonin at $0.1,1$, and $5 \mu \mathrm{g} / \mathrm{mL}$ respectively, compared to the vehicle control (VC) group. The experimental test groups showed significant increased serotonin by $22.5 \%, 34.8 \%, 59.3 \%$, and $38.9 \%$ at $0.1,1,10$, and $25 \mu \mathrm{g} / \mathrm{mL}$ respectively, in the UT-Med + BT-TI, while significant increased serotonin by $55.6 \%$ and $39.7 \%$ at 1 and $10 \mu \mathrm{g} / \mathrm{mL}$ respectively, in the BT-Med + UT-TI, and BT-Med + BT-TI group showed significant increased serotonin by $100.1 \%, 46.6 \%, 8.5 \%$, and $14 \%$ at $0.1,1,10$, and $25 \mu \mathrm{g} / \mathrm{mL}$ respectively as compared to the UT-Med + UT-TI group (Figure 6). Overall, the data suggested that Biofield Energy Healing Treated test formulation significantly improved the serotonin level, which would be highly useful against various neurodegenerative diseases and improved brain functioning.

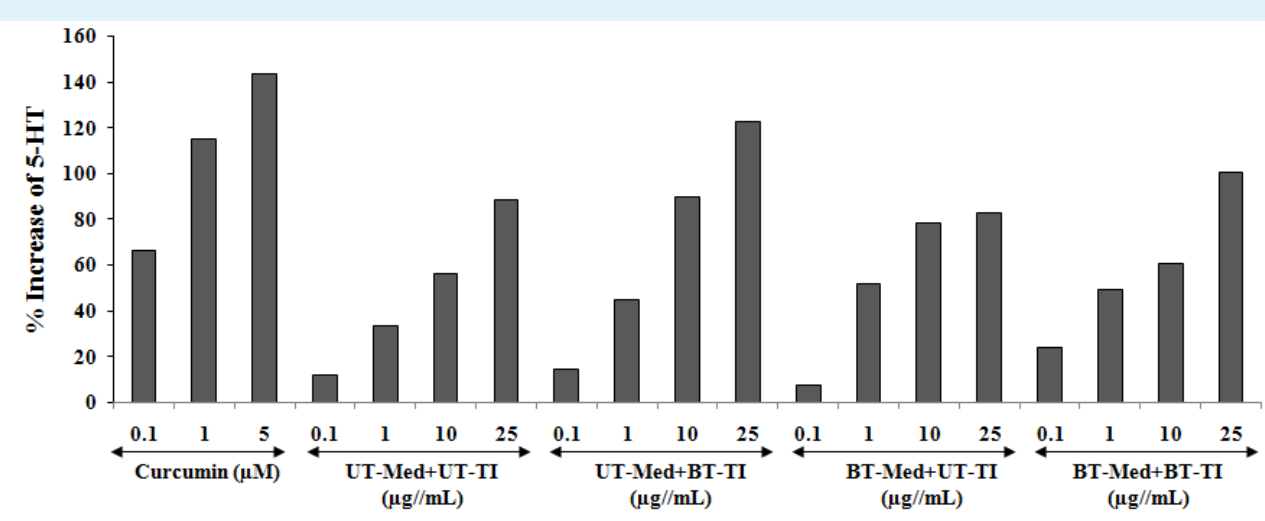

Figure 6: Effect of the test formulation on percent increase in 5-hydroxy tryptamine (5-HT) or serotonin in human neuroblastoma cells (SH-SY5Y). UT: Untreated; Med: Medium; BT: Biofield Treated; TI: Test item. 


\section{Effect of Test Formulation on Vitamin D Receptors (VDRS)}

Human bone osteosarcoma cells (MG-63) are the best in vitro activity testing method for the estimation of vitamin D receptors (VDR) activity after treatment with the test formulation in different experimental groups. VDRs expression and its stabilizing action depend upon the ligand binding through vitamin $\mathrm{D}$ active molecule, which can be estimated using quantitative-polymerase chain reaction (qPCR) amplification. Using real time PCR, different VDR-relative threshold cycle $\left(\mathrm{VDR}-\mathrm{C}_{\mathrm{T}}\right.$ ) values were obtained after complete amplification cycles. Relative quantification (RQ) was calculated from the VDR$\mathrm{C}_{\mathrm{T}}$ and house-keeping (HK)- $\mathrm{C}_{\mathrm{T}}$ values in MG-63 cells. The values after treated with the test formulation and positive control are represented in Figure 7. Calcitriol, was used as a positive control and the RQ of VDR was found to be increased in concentration-dependent manner by $22.3 \%$, $46.4 \%$, and $171.3 \%$ at 1,10 , and $100 \mathrm{nM}$, respectively. The experimental test groups showed increased RQ of VDR expression by $17.9 \%, 26.3 \%, 82.6 \%$, and $150.6 \%$ in the UT-Med + BT-TI group at $0.1,1,10$, and $50 \mu \mathrm{g} / \mathrm{mL}$ respectively, while $132.4 \%, 380.1 \%$, and $285.3 \%$ at 1,10 , and $50 \mu \mathrm{g} / \mathrm{mL}$ respectively, in the BT-Med + UT-TI group, and increased RQ of VDR by $123.5 \%$ and $148.1 \%$ at 10 and $50 \mu \mathrm{g} / \mathrm{mL}$ respectively, in the BT-Med + BT-TI group as compared to the UT-Med + UT-TI group. Thus, experimental results concluded that Biofield Energy Treatment significantly improved the VDR expression in the tested cell lines. However, 1,25-dihydroxyvitamin D is known as calcitriol, one of the active form of vitamin D ligate with VDRs and regulates the calcium homeostasis, immunity, overall cellular growth and differentiation [17]. Calcitriol can be degraded by many potential vitamin D targets such as colon, prostate, breast, lung, and pancreas. Vitamin D controls various metabolisms and it's up and down regulation is one of the major factor in improving quality of life [56,57]. The data suggested that VDR activity was significantly improved by Biofield Energy Treated test formulation that could be to higher binding capacity towards active vitamin $\mathrm{D}_{3}$ metabolites and that ultimately can improve overall bone cell growth and development.

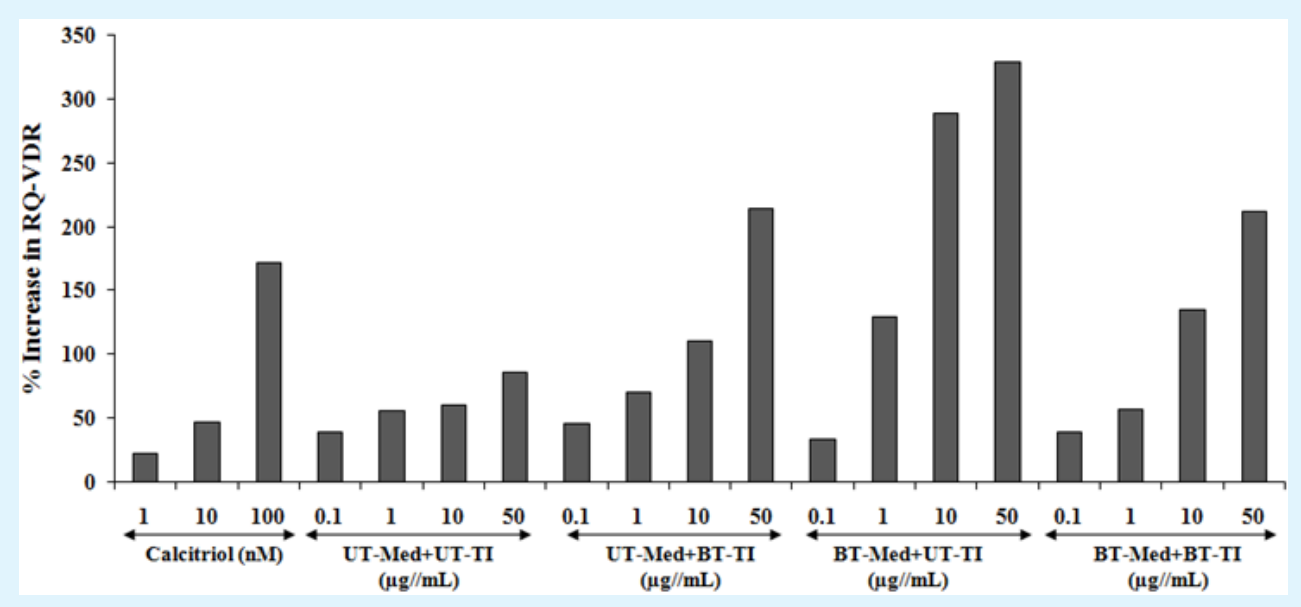

Figure 7: Effect of the test formulation on percent increase in relative quantification (RQ) of vitamin D receptors (VDRs) gene in human bone osteosarcoma cells (MG-63).UT: Untreated; Med: Medium; BT: Biofield Treated; TI: Test item.

\section{Conclusions}

The test formulation was tested in various group combinations with Biofield Energy Treated and untreated test formulation groups and was found safe and non-toxic using standard MTT cell viability assay against tested cell lines with more than $70 \%$ cell viability in all six cells. Cytoprotective activity against $t$-BHP induced cell damage was tested using human cardiac fibroblasts cells (HCF), which showed maximum restoration of cell viability by $156.9 \%$ at $1 \mu \mathrm{g} / \mathrm{mL}$ in UT-Med + BT-TI group, while in HepG2 cells the maximum restoration of cell viability was $94.5 \%$ at $25.5 \mu \mathrm{g} / \mathrm{mL}$ in the UT-Med + BT-TI group, and the test formulation in A549 cells showed maximum restoration of cell viability by $92.4 \%$ at $63.75 \mu \mathrm{g} / \mathrm{mL}$ in the BT-Med + BT-TI group as compared with the untreated test group. Similarly, ALP activity in MG-63 cells showed significantly increased activity by $80.2 \%$ and 


\section{Open Access Journal of Pharmaceutical Research}

93.5\% at 10 and $50 \mu \mathrm{g} / \mathrm{mL}$ respectively, in the UT-Med + BT-TI, while $78.3 \%$ and $85.1 \%$ at 10 and $50 \mu \mathrm{g} / \mathrm{mL}$ respectively, in the BT-Med + UT-TI group, and $19.2 \%$, $76.3 \%$, and $84 \%$ improved cellular protection at 1,10 and $50 \mu \mathrm{g} / \mathrm{mL}$ respectively, in the BT-Med + BT-TI group, as compared to the UT-Med + UT-TI group. Similarly, ALP activity in Ishikawa cells with maximum cellular protection was reported by $51.5 \%$ at $1 \mu \mathrm{g} / \mathrm{mL}$ in UT-Med + BT-TI test group as compared with the untreated test group. The LDH activity was significantly decreased and the data was presented in increased percentage cellular protection data, which showed maximum cellular protection by $156.9 \%$ at $1 \mu \mathrm{g} / \mathrm{mL}$ concentration in the UT-Med + BT-TI group as compared to the untreated test group. ALT activity was studied and data showed maximum improved cellular protection of HepG2 cells (decreased of ALT activity) by $93.1 \%$ and $64.1 \%$ at 1 $\mu \mathrm{g} / \mathrm{mL}$ in UT-Med + BT-TI and BT-Med + UT-TI groups respectively, as compared with the untreated test group. SOD activity was significantly increased by $20.6 \%$ and $12.8 \%$ at 0.1 and $63.8 \mu \mathrm{g} / \mathrm{mL}$ respectively, in the UT-Med + BT-TI group as compared with the untreated test group. Serotonin level was significantly increased in SH-SY5Y cells by $59.3 \%$ (at $10 \mu \mathrm{g} / \mathrm{mL}$ ), $55.6 \%$ (at $1 \mu \mathrm{g} / \mathrm{mL}$ ), and $100.1 \%$ (at $0.1 \mu \mathrm{g} / \mathrm{mL}$ ) in UT-Med + BT-TI, BT-Med + UT$\mathrm{TI}$, and BT-Med + BT-TI groups respectively as compared with the untreated test group. However, VDR expression was tested in MG-63 cells, which showed increased RQ of VDR by $82.6 \%$ and $150.6 \%$ in the UT-Med + BT-TI group at 10 and $50 \mu \mathrm{g} / \mathrm{mL}$ respectively, while $132.4 \%, 380.1 \%$, and $285.3 \%$ increased RQ of VDR at 1,10 , and $50 \mu \mathrm{g} / \mathrm{mL}$ respectively, in the BT-Med + UT-TI group, and increased RQ of VDR by $123.5 \%$ and $148.1 \%$ at 10 and $50 \mu \mathrm{g} / \mathrm{mL}$ respectively, in the BT-Med + BT-TI group as compared to the untreated test control group. Overall, it can be concluded that the Biofield Energy based test formulation would be the best alternative treatment strategy for improved functioning of heart, liver, bones, neuronal, and lungs parameters against any oxidative stress or damage induced by free radicals. Thus, results suggested that Biofield Energy Treatment can be used as a complementary and alternative treatment for the prevention of various types of cardiac disorders such as stroke, thromboembolic disease, congestive heart failure, congenital heart disease, peripheral artery disease, rheumatic heart disease, valvular heart disease, and venous thrombosis, etc. Besides, it would also protect against many hepatic disorders (cirrhosis, liver cancer, hemochromatosis, Wilson disease), lungs disorders (asthma, chronic bronchitis, emphysema, cystic fibrosis, and pneumonia), and many immune system related disorders. In addition, this novel test formulation can also be utilized for organ transplants (i.e., kidney, liver, and heart transplants), hormonal imbalance, aging, and various inflammatory and immune-related disease conditions like Irritable Bowel Syndrome (IBS), Asthma, Aplastic Anemia, Graves' Disease, Hashimoto Thyroiditis, Multiple Sclerosis, Dermatitis, Alzheimer's Disease (AD), Diabetes, Parkinson's Disease, Myasthenia Gravis, Ulcerative Colitis (UC), Atherosclerosis, etc. to improve overall health and Quality of Life.

\section{Acknowledgements}

Authors gratefully acknowledged to Trivedi Global, Inc., Trivedi Science, and Trivedi Master Wellness for their support. In addition, authors are thankful for the support of Dabur Research Foundation for conducting this study.

\section{Conflicts of Interest}

The authors declare no conflicts of interest.

\section{References}

1. Lee NH, Yoo SR, Kim HG, Cho JH, Son CG (2012) Safety and tolerability of Panax ginseng root extract: A randomized, placebo-controlled, clinical trial in healthy Korean volunteers. J Altern Complement Med 18(11): 1061-1069.

2. Coleman CI, Hebert JH, Reddy P (2003) The effects of Panax ginseng on quality of life. J Clin Pharm Ther 28(1): 5-15.

3. Ryan-Harshman M, Aldoori W (2005) Health benefits of selected minerals. Can Fam Physician 51(5): 673675.

4. Rayman MP (2000) The importance of selenium to human health. Lancet 356: 233-241.

5. Beard JL, Connor JR (2003) Iron status and neural functioning. Ann Rev Nutr 23: 41-58.

6. Das L, Bhaumik E, Raychaudhuri U, Chakraborty R (2011) Role of nutraceuticals in human health. J Food Sci Technol 49(2): 173-183.

7. Bodeker G, Ong CK, Grundy CK, Burford G, Shein K (2005) WHO Global Atlas of Traditional, Complementary and Alternative Medicine. World Health Organization pp: 1-120. 


\section{Open Access Journal of Pharmaceutical Research}

8. Bandaranayake WM (2006) Quality control, screening, toxicity, and regulation of herbal drugs. Modern Phytomedicine. Turning Medicinal Plants into Drugs, Ahmad I, Aqil F, Owais M, (Eds.) pp: 25-57.

9. Czekanska EM, Stoddart MJ, Richards RG, Hayes JS (2012) In search of an osteoblast cell model for in vitro research. Europ Cells Mat 24: 1-17.

10. Schaefer WR, Fischer L, Deppert WR, Hanjalic-Beck A, Seebacher L, et al. (2010) In vitro-Ishikawa cell test for assessing tissue-specific chemical effects on human endometrium. Reprod Toxicol 30(1): 89-93.

11. Valavanidis A, Vlachogianni T, Fiotakis K, Loridas S (2013) Pulmonary oxidative stress, inflammation and cancer: respirable particulate matter, fibrous dusts and ozone as major causes of lung carcinogenesis through reactive oxygen species mechanisms. Int J Environ Res Public Health 10(9): 3886-3907.

12. Bouma ME, Rogier E, Verthier N, Labarre C, Feldmann G (1989) Further cellular investigation of the human hepatoblastoma-derived cell line HepG2: Morphology and immunocytochemical studies of hepatic-secreted proteins. In Vitro Cell Dev Biol 25: 267-275.

13. Bak MJ, Jun M, Jeong WS (2012) Antioxidant and hepatoprotective effects of the red ginseng essential oil in $\mathrm{H}(2) \mathrm{O}(2)$-treated hepG2 cells and $\mathrm{CCl}(4)$ treated mice. Int J Mol Sci 13(2): 2314-2330.

14. Molavi B, Mehta JL (2004) Oxidative stress in cardiovascular disease: molecular basis of its deleterious effects, its detection, and therapeutic considerations. Curr Opin Cardiol 19(5): 488-493.

15. Meneses A, Liy-Salmeron G (2012) Serotonin and emotion, learning and memory. Rev Neurosci 23(5-6): 543-553.

16. Rohm B, Holik AK, Somoza MM, Pignitter M, Zaunschirm M, Ley JP, et al. (2013) Nonivamide, a capsaicin analog, increases dopamine and serotonin release in SH-SY5Y cells via a TRPV1-independent pathway. Mol Nutr Food Res 57(11): 2008-2018.

17. Haussler MR, Whitfield GK, Haussler CA, Hsieh JC, Thompson PD, et al. (1998) The nuclear vitamin D receptor: Biological and molecular regulatory properties revealed. J Bone Miner Res 13(3): 325349.
18. Brown AJ, Brown AJ, Slatopolsky E (1999) Vitamin D. Am J Physiol Renal Physiol 277(2): F157-F175.

19. IHME (2017) Global Burden of Disease Collaborative Network. Global Burden of Disease Study 2016 (GBD 2016). Institute for Health Metrics and Evaluation, United States.

20. Pal S (2018) Incidence and prevalence of major neurologic disorders. US Pharm 43(1): 24.

21. Movaffaghi Z, Farsi M (2009) Biofield therapies: Biophysical basis and biological regulations. Complement Ther Clin Pract 15(1): 35-37.

22. Barnes PM, Powell-Griner E, McFann K, Nahin RL (2004) Complementary and alternative medicine use among adults: United States, 2002. Adv Data 343: 119.

23. Barnes PM, Bloom B, Nahin RL (2008) Complementary and alternative medicine use among adults and children: United States, 2007. Natl Health Stat Report 12: 1-23.

24. Fan K wai (2005) National Center for Complementary and Alternative Medicine Website. J Med Libr Assoc 93: 410-412.

25. Trivedi MK, Tallapragada RM (2008) A transcendental to changing metal powder characteristics. Met Powder Rep 63(9): 22-28, 31.

26. Trivedi MK, Nayak G, Patil S, Tallapragada RM, Latiyal O (2015) Studies of the atomic and crystalline characteristics of ceramic oxide nano powders after bio field treatment. Ind Eng Manage 4: 161.

27. Trivedi MK, Branton A, Trivedi D, Nayak G, Mondal SC, et al. (2015) Morphological characterization, quality, yield and DNA fingerprinting of biofield energy treated alphonso mango (Mangifera indica L.). Journal of Food and Nutrition Sciences 3: 245-250.

28. Trivedi MK, Branton A, Trivedi D, Nayak G, Charan S, et al. (2015) Phenotyping and 16S rDNA analysis after biofield treatment on Citrobacter braakii: A urinary pathogen. J Clin Med Genom 3: 129.

29. Trivedi MK, Patil S, Shettigar H, Mondal SC, Jana S (2015) Evaluation of biofield modality on viral load of Hepatitis B and C viruses. J Antivir Antiretrovir 7(3): 83-88. 


\section{Open Access Journal of Pharmaceutical Research}

30. Trivedi MK, Patil S, Shettigar H, Bairwa K, Jana S (2015) Phenotypic and biotypic characterization of Klebsiella oxytoca: An impact of biofield treatment. J Microb Biochem Technol 7(4): 202-205.

31. Nayak G, Altekar N (2015) Effect of biofield treatment on plant growth and adaptation. J Environ Health Sci 1: $1-9$.

32. Branton A, Jana S (2017) The influence of energy of consciousness healing treatment on low bioavailable resveratrol in male Sprague Dawley rats. International Journal of Clinical and Developmental Anatomy 3(3): 9-15.

33. Branton A, Jana S (2017) The use of novel and unique biofield energy healing treatment for the improvement of poorly bioavailable compound, berberine in male Sprague Dawley rats. American Journal of Clinical and Experimental Medicine 5(4): 138-144.

34. Kinney JP, Trivedi MK, Branton A, Trivedi D, Nayak G, et al. (2017) Overall skin health potential of the biofield energy healing based herbomineral formulation using various skin parameters. American Journal of Life Sciences 5(2): 65-74.

35. Singh J, Trivedi MK, Branton A, Trivedi D, Nayak G, et al. (2017) Consciousness energy healing treatment based herbomineral formulation: A safe and effective approach for skin health. American Journal of Pharmacology and Phytotherapy 2(1): 1-10.

36. Trivedi MK, Branton A, Trivedi D, Nayak G, Plikerd WD, et al. (2017) A Systematic study of the biofield energy healing treatment on physicochemical, thermal, structural, and behavioral properties of magnesium gluconate. International Journal of Bioorganic Chemistry 2(3): 135-145.

37. Trivedi MK, Patil S, Shettigar H, Mondal SC, Jana S (2015) The potential impact of biofield treatment on human brain tumor cells: A time-lapse video microscopy. J Integr Oncol 4(3): 141.

38. Anagnos D, Trivedi K, Branton A, Trivedi D, Nayak G, et al. (2018) Influence of biofield treated vitamin $\mathrm{D}_{3}$ on proliferation, differentiation, and maturation of bone-related parameters in MG-63 cell-line. International Journal of Biomedical Engineering and Clinical Science 4(1): 6-14.
39. Lee AC, Trivedi K, Branton A, Trivedi D, Nayak G, et al. (2018) The potential benefits of biofield energy treated vitamin $\mathrm{D}_{3}$ on bone mineralization in human bone osteosarcoma cells (MG-63). International Journal of Nutrition and Food Sciences 7(1): 30-38.

40. Stutheit ME, Trivedi K, Branton A, Trivedi D, Nayak G, Mondal SC, Jana S (2018) Biofield energy treated vitamin D3: Therapeutic implication on bone health using osteoblasts cells. American Journal of Life Sciences 6(1): 13-21.

41. Alía M, Ramos S, Mateos R, Bravo L, Goya L (2005) Response of the antioxidant defense system to tertbutyl hydroperoxide and hydrogen peroxide in a human hepatoma cell line (HepG2). J Biochem Mol Toxicol 19(2): 119-128.

42. Vargas-Mendoza N, Madrigal-Santillán E, MoralesGonzález A, Esquivel-Soto J, Esquivel-Chirino C, et al. (2014) Hepatoprotective effect of silymarin. World J Hepatol 6(3): 144-149.

43. Videla LA (2009) Oxidative stress signaling underlying liver disease and hepatoprotective mechanisms. World J Hepatol 1(1): 72-78.

44. Sha Li, Hor-Yue Tan, Ning Wang, Zhang-Jin Zhang, Lixing Lao, et al. (2015) The role of oxidative stress and antioxidants in liver diseases. Int J Mol Sci 16(11): 26087-26124.

45. Cheresh P, Kim SJ, Tulasiram S, Kamp DW (2013) Oxidative stress and pulmonary fibrosis. Biochim Biophys Acta 1832(7): 1028-1040.

46. Lu LY, Ou N, Lu QB (2013) Antioxidant induces DNA damage, cell death and mutagenicity in human lung and skin normal cells. Sci Rep 3: 3169.

47. Atkins GJ, Findlay DM, Anderson PH, Morris HA (2011) Vitamin D (3 ${ }^{\text {rd }}$ Edn.). Target Genes: Bone Proteins 1(23): 411-424.

48. Emami A, Larsson A, Petrén-Mallmin M, Larsson S (1999) Serum bone markers after intramedullary fixed tibial fractures. Clin Orthop Relat Res 368: 220229.

49. Burgner JW, Ray WJ (1984) On the origin of the lactate dehydrogenase induced rate effect. Biochemistry 23(16): 3636-3648. 
50. Valvona CJ, Fillmore HL, Nunn PB, Pilkington GJ (2015) The regulation and function of lactate dehydrogenase A: Therapeutic potential in brain tumor. Brain Pathol 26(1): 3-17.

51. Kopperschläger G, Kirchberger J (1996) Methods for the separation of lactate dehydrogenases and clinical significance of the enzyme. J Chromatogr B Biomed Appl 684(1-2): 25-49.

52. Pratt DS, Kaplan MM (2000) Evaluation of abnormal liver-enzyme results in asymptomatic patients. N Engl J Med 342(17): 1266-1271.

53. Mathiesen U, Franzen L, Fryden A, Foberg U, Bodemar G (1999) The clinical significance of slightly to moderately increased liver transaminase values in asymptomatic patients. Scand J Gastroenterol 34(1): 85-91.
54. Birben E, Sahiner UM, Sackesen C, Erzurum S, Kalayci $O$ (2012) Oxidative stress and antioxidant defense. World Allergy Organ J 5(1): 9-19.

55. Meltzer CC, Smith G, DeKosky ST, Pollock BG, Mathis CA, et al. (1998) Serotonin in aging, late-life depression, and Alzheimer's disease: the emerging role of functional imaging. Neuropsychopharmacology 18(6): 407-430.

56. Hollis BW (2005) Circulating 25-hydroxyvitamin D levels indicative of vitamin D sufficiency: implications for establishing a new effective dietary intake recommendation for vitamin D. J Nutr 135: 317-322.

57. Carlberg C, Molnár F (2012) Current status of vitamin D signaling and its therapeutic applications. Curr Top Med Chem 12(6): 528-547. 